\title{
Analysis of the Temple Economy in the Tang Dynasty and the Thinking of the "Commercialization" of Buddhist Temples
}

\author{
Yuying Jiang ${ }^{1, *}$ \\ ${ }^{1}$ Beijing Institute of Technology, Zhuhai, School of Civil and Commercial Law, Zhuhai, China, 519008 \\ *Corresponding author. Email: zhbit@bizth.edu.cn
}

\begin{abstract}
After Buddhism introduced into China from the Eastern Han Dynasty, through the development of successive dynasties, its unique temple economy is also in the process of constant development and change. This paper mainly introduces the development course and business model of the temple economy in the Tang Dynasty, and its influence on the society at that time. In addition, based on the status quo and commercialization of temples in contemporary society, it has extended some thoughts on the "commercialization" of modern Chinese temples.
\end{abstract}

Keywords : Temple economy, Tang Dynasty, Commercialization

\section{INTRODUCTION}

Buddhism, as one of the three major religions in the world, has been developing continuously since it was introduced into China in the Eastern Han Dynasty and formed a Chinese version of Buddhism. As an important Buddhism flourished in the Tang dynasty history, the temple economy is less understood, which is formed by the now under economic development gradually. The consumption demand of people for the spiritual life is also gradually increasing. Due to deep the influence of Buddhism in China, many places of interest to the above are located in the beautiful mountains and rivers and attract large numbers of tourists to visit. This has led to discussions about Buddhism and the commercialization of monasteries in China.

This paper specifically from the following three aspects to carry on the analysis. The first aspect of temple economy with it development history and its business model to carry on the simple introduction. At the same time, this paper briefly compares the development status of temples in contemporary society. The second part analyzes in the Tang Dynasty temple economy bring the influence of different level. Finally this paper compares the commercialization phenomenon of Buddhism and temples in the Tang Dynasty and in modern society.

\section{THE DEVELOPMENT AND MODELS OF TEMPLE ECONOMY IN THE TANG DYNASTY AND IN MODERN SOCIETY}

\subsection{The development of the temple economy}

\subsubsection{In the Tang Dynasty}

The economic development of temples in the Tang Dynasty has gone through five more important stages. Li Yuan, who established the Tang Dynasty, believed in Buddhism. After he became emperor, he began to build temples. Purdue monks and nuns. Although Li Shimin, Emperor Taizong of the Tang Dynasty, did not believe in Buddhism, he believed that Buddhism was established. The propagated "charity-based" ideas can make people understand good and evil, know the cause and effect, stabilize the people's mind, and stabilize the country. Later, when Princess Wencheng entered Tibet, a large number of Buddhist scriptures and statues in her dowry also promoted the development of Buddhism in Tibetan areas to a certain extent[1]. When $\mathrm{Wu}$ Zetian was a monk in Ganye Temple in her early years, she had studied Buddhism to some extent. When she created public opinion to proclaim herself emperor, several monks and nuns at that time made great efforts to create public opinion so that she could legally proclaim herself emperor. Therefore, she elevated the status of Buddhism 
and conferred titles on several monks and nuns as national teachers. After the reign of Zhenguan, Buddhism enjoyed unprecedented prosperity in the continuous development, and the monastery economy also fully developed. It was not until the period of Huichang that Emperor Wuzong of the Tang Dynasty attacked Buddhism on a large scale by using the state power, which made Buddhism in the Tang Dynasty decline and the temple economy lost its strong support and could not recover.

\subsubsection{In modern society}

After the 1951 land reform movement, the monastery fields were redistributed according to the policy. Except for some mountainous monasteries operating forest farms, orchards or farms, other monasteries set up sacks factories, clothing processing factories, etc., and basically achieved self-support. In order to achieve "self-support", after the reform and opening up, many temples have begun to collect tickets, place a letter box, and conduct religious and legal activities. National policies also actively guide Buddhism to adapt to the social system.

\subsection{The business models of temple economy in the Tang Dynasty and modern society}

\subsubsection{In the Tang Dynasty}

Compared with other dynasties, the monastery economy in the Tang Dynasty has a large amount of land that has become an important guarantee for the development of the monastery economy, and thus formed a new structure of the temple economy in the Tang Dynasty. Although the sources of subdivided land are more extensive,it was based on the Tang dynasty system of equal land, in which men and women were allotted separate plots of land according to rules, and monks and nuns were allotted the same. Under the implementation of this system, the monasteries not only owned a large amount of land, but also enjoyed exemption from taxes and military service.

The land sources of temples in the Tang Dynasty are mainly divided into the following aspects: Because of these privileges, The field resources of the monastery were divided into land grants from the state and alms from wealthy aristocratic families. Some wealthy families, in order to avoid military service, had their sons cut off their hair to become monks, and the land was also donated to the monasteries as alms [2]. Since Buddhism did not enter China only from the Tang Dynasty, after the accumulation of previous dynasties, many temples originally held a considerable amount of land. On this basis, with the addition of land cultivated by the monks themselves, the scale of the temples continued to grow. At the same time, the donations given by the imperial court to people who believed in Buddhism at that time also increased the land resources owned by the temple. In this situation, farmers have less arable land, and this has developed the two pillars of the monastery economy, real estate and usury, and a large number of monastery slaves in the monastery acted as labor, making the monastery economy develop rapidly and become an important part of the economy in the entire country [3].

The formation of the business model is based on "self-offering" but not only the monk's own labor results, but also a large number of net people and farmers to work together. "Net men" are the most common people driven into slavery by monasteries, and all the income they earn from their labour is given to the monasteries. The temple's business model consists mainly of leasing land to farmers for fortition, lending at usury, and also running hotels, handicrafts, or selling items and Buddhist uses [4].

Due to the vast land area, temples are like wealthy merchants when they obtain farmland while planting trees, fruits or tea, flowers or spices, most of which are sold, and at the same time develop animal husbandry, making this kind of garden products and temple animal husbandry have obvious characteristics of commodity production. In addition to plantation nursery products or crops, some monasteries are proficient in medicine, and many people go to the monastery to seek medical advice. Therefore, the medicines planted or collected in the monasteries can not only be used to treat people's diseases, but also can be taken to sale on the market. Doing a lot of good and accumulating virtue is a major event in Buddhism, which also makes the business behavior of monks treating patients and making medicines to a certain degree of charity, so medicines have an important position in the sales of monasteries [5].

In addition to the sale of ordinary goods, some national temples or high-profile monasteries may be due to royal nobles, rich merchants gifts contain some jewelry, antiques or clothing and other luxury goods, one of which is already very valuable, but because the number is small and not every monastery will have the opportunity to trade luxury goods, so the commercial behavior of the luxury goods transaction is more limited. In the pre-Tang Dynasty advocating Buddhism in the social atmosphere, the rise of Buddhism has increased people's demand for Buddhist scriptures, Buddha statues and other Buddhist things, whether the royal nobles or ordinary people want to serve Buddha statues or recite some scriptures, resulting in a large number of Buddhist scriptures need to be translated, Buddha statues are also in short supply, there are also some people specializing in translating and writing Buddhist scriptures, making Buddha statues. 
Business and land mergers have brought huge wealth to monasteries or monks, but the methods of obtaining wealth are not limited to these two. The lending industry in the Tang Dynasty was like the continuous accumulation of land resources. It had a rudimentary form during the Wei, Jin, Southern and Northern Dynasties. In the continuous development, the types of lending evolved in various ways, but in general, they were mainly divided into materials without directly Mortgage loans, the other is loans that require collateral. In lending without collateral, under this barter exchange economy, the returned goods may not be the originally borrowed goods, but the returned goods with higher value than the lent goods. However, this seemingly ordinary method of mortgage by property has gradually expanded to usury to all classes of society. Compared with the usury of secular landlords, the monastery's loan interest rate may be higher than the principal under the continuous accumulation of loan interest. In order to recover the principal and interest, some monasteries colluded with the government and asked the government to help collect debts, or fabricated stories about the retribution of those who evaded the debt, which caused many people to repay their debts under the influence of intimidation. Because of this, many people are also under the oppression of loan sharks, leading to family destruction. It may be because of the worship of Buddhism or the good reputation of the temple. Some high-ranking nobles sometimes deposit their money in the temple and let them take care of it. The business of depositing money was most popular in the Tang Dynasty [6].

The number of monasteries in the Tang Dynasty continued to increase, and many of them were located in beautiful scenery or important traffic routes. With the large number of houses and superior geographical location, the monasteries gradually developed "board and lodging" operations. Some provide short-term accommodation, while others can provide long-term leases. Because of the quiet environment, it also attracted many students to live in it. Although the monastery and hotel need to charge a certain fee, it does not affect the living of monks and nuns and pilgrims or people passing by. While propagating the development of Buddhism, it also embodies the compassion and relief of Buddhism, and can also get a lot of income from it. Therefore, accommodation in temples and hotels is quite common [7].

\subsubsection{In modern society}

In addition to ticket income, contemporary monasteries also charge fees for temple facilities and religious items. For example, you need to pay for taking pictures of cultural relics such as Buddha statues in scenic spots. Or compulsorily buy souvenirs in the temple. Use religious festivals to hold pujas or consecration ceremonies, and charge different fees for this. For example, Shaolin Temple participated in movies under the name of martial arts culture, and held martial arts selection competitions with TV stations. Some monasteries set up commercial companies in their own name and expanded to various fields.

\section{THE INFLUENCES OF TEMPLE ECONOMY ON SOCIETY}

\subsection{The positive influences}

The positive influence of temple economy can be analyzed from two aspects. One is that it promotes the progress and development of Buddhism itself. Confucianism, Buddhism and Taoism originally before the Tang dynasty are different religious position. However, because of past dynasties emperor and his ministers worship Buddha, its status is also gradually rise. There are more communication of annotation buddhist translated, making the foundation of Buddhism in China more entrenched into the buddhist theory of the parties in their own ideological progress at the same time. It will also promote the gradual secularization of agricultural Zen thought so that people's ideas guide them to have different thinking about economic behavior [8]. The other aspect of this is that the change of the feudal economic system and the nature of the temple economy itself. Because the temple sold to farmers is not much of the wasteland together and not enough hands to reclaim, farmers concentrated together to reclaim farming. At the same time, operators of tourism and handicraft industry changed the small-scale peasant economy under the relatively independent, small scale farming economy. The development of commodity economy has played a certain role in promoting. Temple economy in a period of time also had set up "compassion, cure, apply medicine" three welfare institutions so that the temple has the nature of social relief [1].

Whether it is ancient or contemporary, the survival of religions needs economic support. The moderate "commercialization" of temples has promoted the display and dissemination of Buddhist culture to the public. Combining the Internet and offline, people can have more opportunities to contact and learn about Buddhism. At the same time, the continuous accumulation of funds can enhance the ability of Buddhist charitable organizations to carry out social welfare, and promote the development of public welfare in the process of developing and promoting Buddhism.

\subsection{The negative influences}

Because the temples have increased because of expanding in financial resources, the constant purchase of land allowed the Buddhist monastery to join the land 
annexation of the secular landlords at that time. This accelerated the collapse of land equalization policy. The temple's own privilege caused less national tax income and wealthy families' children even ordinary people at home will have their strong backing a monk in order to avoid the corvee. In the time of war, the national finance could not raise the military expenditure, and the long-term economic conflict between the feudal state and the Buddhist temple finally broke out. Finally, the temple economy also went into decline with the continuous war in the late Tang Dynasty.

Nowadays, excessive commercialization will make religious venues too secular and lack the content and heritage of Buddhist culture. It may also affect tourists' perception and experience of temples, leading to a vicious circle of economic benefits. A large number of tourists poured into the temple, which brought greater pressure on the ecological environment and cultural relics. For example, some uncivilized tourists used to engrave on the pillars and other behaviors, which is detrimental to the temple itself or the religious culture.

\section{REFLECTIONS ON MODERN BUDDHISM AND THE "COMMERCIALIZATION" OF CHINESE MONASTERIES}

It is not difficult to see from the development course of the temple economy in the Tang Dynasty that the "commercialization" of Buddhism and Chinese temples did not begin to appear from now on, but the ways of expression were different. The prosperity and development of Buddhism and temple economy in the Tang Dynasty is not only the behavior of worshiping Buddhism by emperors and ministers, but also the rapid development of economy in the Tang Dynasty after the reign of Zhenguan. Large-scale construction and repair of Buddha statues, construction of temples, and unreasonable management have caused contradictions to continue to worsen. At the early stage of the Tang GaoZu period, account is to bolster the Buddhism and to have certain restriction, not only because of the economy has yet to be restored, the people did not live and do not have enough economic strength to support Buddhism. It is necessary to have a certain business belief, and absorb the experience of the Sui Dynasty. Sui Dynasty extensively built Buddhist temples, regardless of the people's livelihood, leading to the decline of the Sui Dynasty. Therefore, Buddhism, with certain restrictions, played a positive role in economic recovery while also laying the groundwork for its own prosperity and development. It is not impossible to be "commercialized", because religion and economy are inseparable, which is a permanent and mutually maintained and promoted relationship, so the "commercialization" of modern Buddhism and temples is necessary, just like the "self-confession" model of temple economy. Contemporary indigenous Buddhism has also figured out and been allowed to use business methods within reasonable limits to maintain the normal operation of the monastery.

The existence of "commercialization" must have certain limits. Acts such as selling high-priced tickets, investing in and operating religious sites for illegal gains, even listing as corporate assets, and hiring fake monks and nuns should be severely punished by law [9]. At the same time, special personnel or departments are assigned to conduct statistics and management of the economic income of the monasteries, and strictly control the quality of monks and nuns. It can also be combined with the Internet and other information platforms to promote Buddhism to the public and believers, and promote the healthy development of religious culture.

\section{CONCLUSION}

The modern "commercialized" monastery economy is not only centered on the monastery itself. In addition to gaining ticket income through the monastery, a tourist monument, some of the more famous monasteries have registered their names as trademarks and started businesses; they cooperated with TV stations. Martial arts performance or competition. Pure temples have become overcrowded, and the propaganda and development of Buddhist culture has become inseparable from commercialized operations. Relying on Buddhist culture, commercialized behaviors can expand its influence and promote Buddhist culture. The relationship between religion and economy is mutually influenced and permeated. The introduction of Buddhism serves as a need for cultural development and plays a role in stabilizing the country. The development of the new era should also encourage Buddhists to give lectures, and guide people to work towards a better life [10].

Indigenized Buddhism and monasteries need to be preserved as cultural treasures, but at the same time they need to be revitalized. The "commercialization" of Buddhism and monastic practices should not be understood as a derogatory term, but as a new model worthy of development that allows Buddhism to discipline itself. In the process of promoting Buddhist culture and conveying the true meaning of Buddhism, ordinary people can feel Buddhist culture in the process of traveling and so on. It will be realized that organizing reasonable religious ceremonies, exploring a new commercialization path, and consciously resisting illegal behavior.

\section{AUTHORS' CONTRIBUTIONS}

This paper is independently completed by Yuying Jiang. 


\section{ACKNOWLEDGMENTS}

Many thanks to my teachers for helping me broaden my thinking in the framework of the thesis thinking in the process of guiding the thesis. The teachers also patiently exchanged the details of the paper with me and put forward suggestions for revision, so that I can complete this paper smoothly. Great thanks to my teachers.

\section{REFERENCES}

[1] Xinrong Liu. On the influence of Buddhism on the economic development of the Tang Dynasty [J]. Lantai World, 2015, 000(027): 91-92.

[2] Chengsi Wei. The rise and fall of economy and Buddhism in the Tang Dynasty [J]. The Voice of Dharma, 1988(04):4-9.

[3] Shiqiang Chen. The general trend and signs of the economic development of temples in the Han and Tang Dynasties [J]. Fudan Journal: Social Sciences Edition, 1986(02):78-82.

[4] Guohuan Chen, Jie Du. Analysis of the positive influence of Buddhism on the economic development of the Tang Dynasty [J]. Jintian, 2012(7):104-104.

[5] Yanyan Han. "Huichang Law Difficulty" in Tang Dynasty and the transformation of monastery economic development model [D]. Jiangxi Normal University, 2015.

[6] Chongguang Xie. The commerce and loan industry in the Jin and Tang monasteries [J]. Researches in Chinese Economic History, 1989(01):49-66.

[7] Jinfeng Chen, Zhen Li. A Preliminary Study on the Temple Hotel Industry in the Tang Dynasty [J]. Journal of Yichun University, 2016, v.38; No.245(04):1-7.

[8] Rong He. A Preliminary Study of Buddhist Temple Economy and Its Influence [J]. Sociological Study, 2007(4):75-92.

[9] Yanling Wang. The external environment and internal contradictions of the economic development of contemporary Buddhist temples [J]. The World Religious Culture, 2007(3):7-8.

[10] Weishi Wang. Research on the Commercialization of Buddhism in Contemporary my country [D]. Southwest University, 2015. 